\section{Intranasal Steroid and Asthma}

Keywords: Intranasal steroid therapy; Asthma; Atopy; On demand intranasal steroid therapy (ODIST); Eco nomy under developed country

\begin{abstract}
A non randomized, active controlled trial was done and still is open to recruitment, open label, phase-1 type among few children over two years of age with positive history of atopy, WALRI \& asthma, with intranasal steroid. Intranasal steroid was given in each side of nose with a phial then to follow On Demand Steroid Therapy [ODIST] was advised. Result was noted with their Symptoms Record Book, PEFR, Spirometry \& IgE level.

Objectives were to see its outcome. And its' $R R=1.2, O R=2$. $P$ $=0.02275,[\mathrm{DF}=1, \mathrm{Cl}=1.026-4.203$ at $95 \%$ ]. This can not only help the patients \& parents but also have a great impact on the future economy of under developed country.
\end{abstract}

\section{Introduction}

Asthma is a chronic disease characterized by recurrent attacks of breathlessness and wheezing which vary in severity and frequency from person to person [1]. Symptoms may occur several times in a day or week in affected individuals, and for some people become worse during physical activity or at night. During an asthma attack, the lining of the bronchial tubes swell, causing the airways to narrow and reducing the flow of air into and out of the lungs [1]. Recurrent asthma symptoms frequently cause sleeplessness, daytime fatigue, reduced activity levels and school and work absenteeism $[2,3]$.

Asthma has a relatively low fatality rate compared to other chronic diseases [4].

During last nine years of office- practice one of the commonest cases has seen is Wheeze Associated Respiratory Infection (WALRI).

WHO estimates that 235 million people currently suffer from asthma? Asthma is the most common chronic disease among children [4].

Asthma is a public health problem not just for high-income countries; it occurs in all countries regardless of the level of development [4]. Most asthma - related deaths occur in low- and lower- middle income countries [4]. Asthma is under - diagnosed and under - treated. It creates substantial burden to individuals and families and often restricts individuals' activities for a life time [4]. There has been a sharp increase in the global prevalence, morbidity, mortality, and economic burden associated with asthma over the last 40 years, particularly in children [4]. Approximately 300 million people worldwide currently have asthma, and its prevalence increases by $50 \%$ every decade. In North America, $10 \%$ of the populations have asthma.

The financial burden on patients with asthma in different Western countries ranges from $\$ 300$ to $\$ 1,300$ per patient per year, disproportionately affecting those with the most severe disease [1].

Among different age groups of children, in different forms this WALRI presented: mild intermittent, mild persistent, moderate

\section{Journal of \\ Pediatrics \& Child Care}

\author{
Rajatsubhra Mukhopadhyay \\ Child Health Care Arambag, Koruna Medical, India \\ *Address for Correspondence: \\ Dr Rajatsubhra Mukhopadhyay, Child Health Care Arambag, Koruna \\ Medical, Hospital More, Arambag, Hooghly, West Bengal, India, Pin- \\ 712601, Phone: 9732948496; E-mail: dr_rajatsubhra@yahoo.com \\ (or) dr_rajatsubhra@sridoctor.com \\ Submission: 28 November, 2016 \\ Accepted: 18 September, 2017 \\ Published: 20 September, 2017 \\ Copyright: (c) 2017 Mukhopadhyay R, et al. This is an open access \\ article distributed under the Creative Commons Attribution License, \\ which permits unrestricted use, distribution, and reproduction in any \\ medium, provided the original work is properly cited.
}

persistent, severe persistent [5].

\section{There are $\mathbf{2}$ main types of childhood asthma:}

(1) Recurrent wheezing-in early childhood, primarily triggered by common viral infections of the respiratory tract. (2) Chronic asthma- associated with allergy that persists into later childhood and often adulthood. A $3^{\text {rd }}$ type of childhood asthma typically emerges in females who develop obesity and early- onset puberty (by $11 \mathrm{yr}$ of age) [1].

Hypersensitive to pollutants-environmental tobacco smoke, ozone) farms or with animals in the home, with increased endotoxin. Triad asthma characteristically associated with hyperplastic sinusitis/ nasal polyposis and hypersensitivity to aspirin and non-steroidal anti-inflammatory medications, rarely has its onset in childhood [1].

The persistent form of childhood asthma is that associated with allergy.

\section{Inhaled Corticosteroids (ICS) \& Intranasal Corticosteroid (INCS)}

The NAEPP guidelines recommend daily ICS therapy as the treatment of choice for all patient $s$ with persistent asthma [6]. ICS therapy has been shown to reduce asthma symptoms, improve lung function, reduce AHR, reduce rescue" medication use and, most important, reduce urgent care visits, hospitalizations, and prednisone use for asthma exacerbations by about 50\%. ICS therapy may lower the risk of death due to asthma. It can achieve all of the goals of asthma management and, as a result, is viewed as first- line treatment for persistent asthma.

There are currently 5 ICSs that are approved by the FDA,

Newer forms are being developed (mometasone furoate) that may

Table 1:

\begin{tabular}{|l|l|l|l|l|l|}
\hline Mild intermittent & 1 & $\leq 2 / \mathrm{w} \mathrm{k}$ & $<2 / \mathrm{m}$ o & $\geq 80$ & $<20$ \\
\hline Mild persistent & 2 & $\begin{array}{l}>2 / \mathrm{wk} \text {, but }<1 \text { time/ } \\
\text { day }\end{array}$ & $>2 / \mathrm{m}$ o & $\geq 80$ & $20-30$ \\
\hline $\begin{array}{l}\text { Moderate } \\
\text { persistent }\end{array}$ & 3 & Daily & $>1 / \mathrm{w} \mathrm{k}$ & $>60-80$ & $>30$ \\
\hline Severe persistent & 4 & Continual & Frequent & $\leq 60$ & $>30$ \\
\hline
\end{tabular}




\section{Table 2:}

\begin{tabular}{|c|c|c|c|}
\hline Drug & Dose & Adult & Child \\
\hline $\begin{array}{l}\text { Methylpred } \\
\text { isolone }\end{array}$ & $\begin{array}{l}2,4,8,16,32 \\
\text { mg tablets }\end{array}$ & $\begin{array}{l}7.5-60 \text { mg daily in a } \\
\text { single dose in AM or } \\
\text { qod as needed for } \\
\text { control }\end{array}$ & $\begin{array}{l}0.25-2 \mathrm{mg} / \mathrm{kg} \text { daily } \\
\text { in single dose in AM } \\
\text { or qod as needed for } \\
\text { control }\end{array}$ \\
\hline Prednisolone & $\begin{array}{l}5 \mathrm{mg} \text { tablets, } \\
5 \mathrm{mg} / 5 \mathrm{cc}, 15 \\
\mathrm{mg} / 5 \mathrm{cc}\end{array}$ & $\begin{array}{l}\text { Shor t-course "burst" } \\
\text { to achieve control: } \\
40-60 \mathrm{mg} / \text { day as } \\
\text { single or } 2 \text { divided } \\
\text { doses for } 3-10 \text { days }\end{array}$ & $\begin{array}{l}\text { Shor t-course } \\
\text { "burst": } 1-2 \mathrm{mg} / \mathrm{kg} / \\
\text { day, maximum } 60 \\
\mathrm{mg} / \text { day for } 3-10 \text { days }\end{array}$ \\
\hline Prednisone & $\begin{array}{l}1,2.5,5,10 \\
20,50 \mathrm{mg} \\
\text { tablets; } 5 \mathrm{mg} / \\
\mathrm{cc}, 5 \mathrm{mg} / 5 \mathrm{cc}\end{array}$ & & \\
\hline
\end{tabular}

\section{Table 3:}

\begin{tabular}{|c|c|c|c|}
\hline Salmeterol & $\begin{array}{l}\text { MDI } 21 \\
\mu \mathrm{g} / \mathrm{p} \text { uff }\end{array}$ & $\begin{array}{l}\text { 2puffs q } 12 \\
\text { hour s }\end{array}$ & $\begin{array}{l}\text { 1-2 puffs q } 12 \\
\text { hour s }\end{array}$ \\
\hline & $\begin{array}{l}\text { DPI } 50 \\
\mu \mathrm{g} / \mathrm{blister}\end{array}$ & $\begin{array}{l}1 \text { blister q } 12 \\
\text { hours }\end{array}$ & $\begin{array}{l}1 \text { blister q } 12 \\
\text { hours }\end{array}$ \\
\hline Formoterol & $\begin{array}{l}\text { DPI } 12 \\
\mu \mathrm{g} / \mathrm{single}- \\
\text { use } \\
\text { capsule }\end{array}$ & $\begin{array}{l}1 \text { capsule q } 12 \\
\text { hours }\end{array}$ & $\begin{array}{l}1 \text { capsule q } 12 \\
\text { hours }\end{array}$ \\
\hline \multicolumn{4}{|c|}{ Combined Medication } \\
\hline $\begin{array}{l}\text { Fluticasone / } \\
\text { Salmeterol }\end{array}$ & $\begin{array}{l}\text { DPI } 100 \text {, } \\
250, \\
\text { or } 500 \\
\mu \mathrm{g} / 50 \mu \mathrm{g}\end{array}$ & $\begin{array}{l}1 \text { inhalation } \\
\text { bid; dose } \\
\text { depends on } \\
\text { severity of } \\
\text { asthma }\end{array}$ & $\begin{array}{l}1 \text { inhalation } \\
\text { bid; dose } \\
\text { depends on } \\
\text { severity of } \\
\text { asthma }\end{array}$ \\
\hline
\end{tabular}

enhance the efficacy- to- safety profile of ICS therapy while allowing for less frequent dosing [7]. ICSs are available in MDIs, DPIs, or in suspension for nebulization.

Fluticasone propionate, mometasone furoate and, to a lesser extent, budesonide are considered " 2 nd generation" ICSs in that they have increased antiinflammatory potency and reduced systemic bioavailability for potential adverse effects, owing to extensive firstpass hepatic metabolism. The selection of the initial ICS dose is based on the determination of disease severity. A fraction of the initial ICS dose is often sufficient to maintain good control after his has been achieved.

Although ICS therapy has been widely used in adults with persistent asthma, its application in children has lagged due to concerns of the potential for adverse effects with chronic use.

Generally, clinically significant adverse effect $s$ that occurs with chronic systemic corticosteroid therapy have not been seen or have been only very rarely reported in children receiving ICSs in recommended doses. The risk of adverse effect $s$ from ICS therapy is related to the dose and frequency with which ICSs are given. High doses $(1,000 \mathrm{~g} /$ day $\geq \mu$ in children) and frequent administration (4 times/day) are more likely to cause local and systemic adverse effects. Children who are maintained on higher ICS doses are also likely to require systemic corticosteroid courses for asthma exacerbations, further increasing the risk of corticosteroid adverse effects.

\section{Intranasal corticosteroid [INCS] therapy for asthma}

There is no well established text document. A few works have done or are going on in this topic. A few works are being cited here. First work was an observation in a cohort study by Dr Robert Adam \& others. This was published in 2002.They drew a co-relation with Asthma \& Intranasal steroid might be there [8].

\section{Method}

Type of Study: Non randomized active controlled trial Intervention Name - Intranasal Steroid in Asthma. Controlled Intervention Name - Comparison between two groups with intranasal steroid \& without intranasal steroid; both of the groups having Asthma /WALRI.

Inclusions Criteria: 1. Among all children over two years of age who were suspected from history \& examination/ who came to office with inhalational therapy from other places.

Those who have higher IgE [upto 15/yea $\mathrm{r}$ as normal cut off value] From Kjellman NM et al.: Serum IgE levels in healthy children quantified by a sandwich technique (PRIST). Clin Allergy 1976; 6: 51-59; Zetterström O, Johansson SG: IgE concentrations measured by PRIST in serum of healthy adults and in patient $s$ with respiratory allergy: A diagnostic approach. Allergy 1981; 36(8): 537-547*

- $\quad$ /- Eosinophil[ $>5 / 100 \mathrm{DC} /$ differencial count. And $>600$ AEC/ Absolute Eosinophil Count].

- Nasal Smea $\mathrm{r}$ for Eosinophil > 5/100 Oil Immersion Field.

- Perianal Excoriation.

- Positive Family History of Atopy [ allergicrhinitis, atopic dermatitis, asthma]

2. For age over 5 years

- $\quad$ Poor PEFR $+[<70]$

- $\quad$ Spirometry [Low PEFR, FVC, FEV1/FVC]

Exclusions Criteria: 1. Age group below 2 years.

2. Single onset of respiratory infection.

3. Difficult to correspond.

4. Associated with other systemic diseases.

Parent's counseling: As our aim was to use Intranasal Steroids without exclusion of any allergen, we do not perform any skin prick test. Because it is required to know the allergens to avoid it or to apply immunotherapy.

1. Their parents were counseled stopping the inhaler steroid / tapering it to stop within few days. They were advised to use intranasal steroid. (In case of longer use of inhalers, e.g. more than 2 years), keeping the b2 stimulant with hand, if needed.

2. They were advised to use the intranasal steroid one phial.

It takes almost one two months to control the allergic process. Then keeping another phial on hand; this one is to be used whenever the parents will feel that their baby might have the attack of wheeze. This should be use $\mathrm{d}$ prior to that, for 5 to 7 days. The parents might use it to their kids, for example, after exposure to hot/cold, change 
ISSN: $2380-0534$

Table 4:

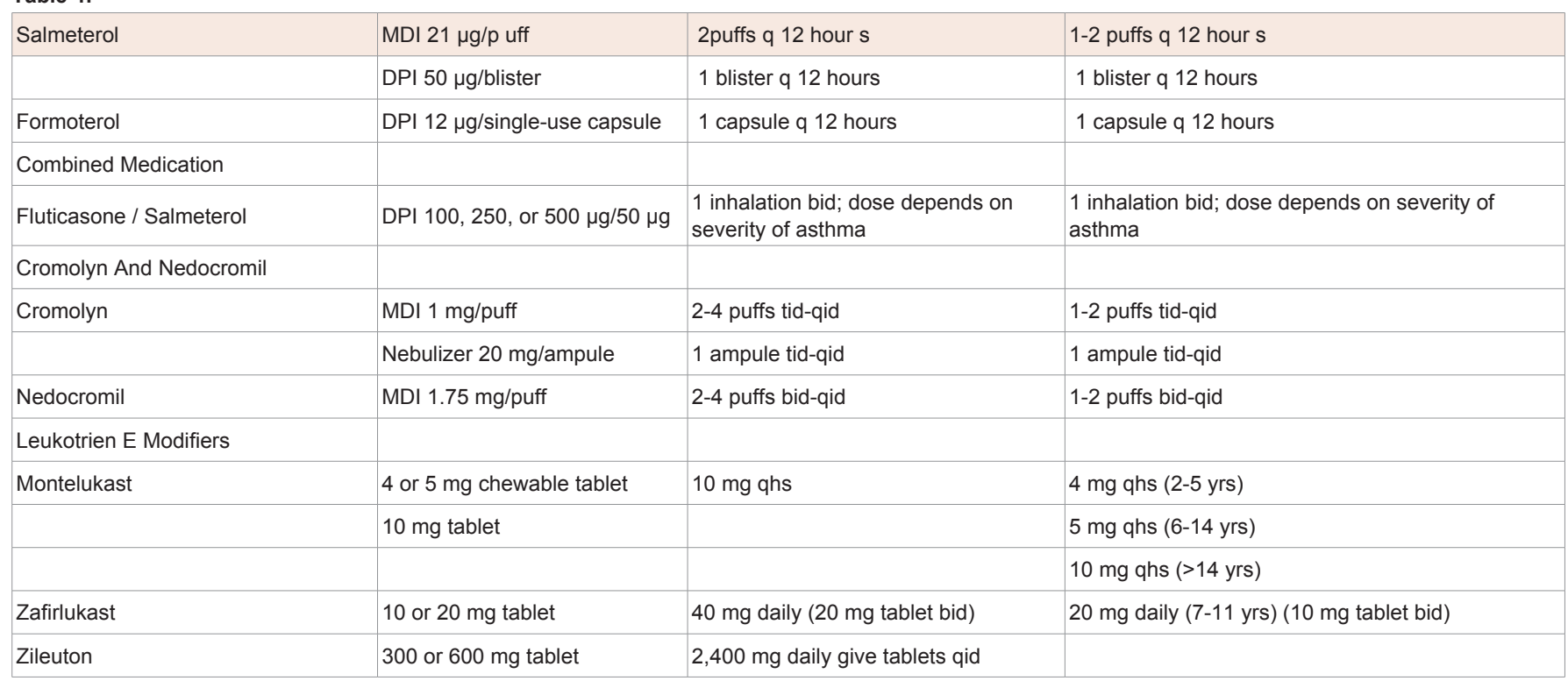

Table 5:

of weather, seasonal changes, outburst of an epidemic of respiratory disease within community/family.

3. To keep a record -book to follow up the future incidences. The record-book contains: Five Columns for Date, Symptoms, Type of medicine used, and duration of the episode [days], Comments.

All of them have their addresses with me to correspond and written consent with me.

There was no method of generating randomization sequence as this was a non randomized trial.

Method of allocation concealment is not applicable.

Blinding \& masking-open label. As there was no stoppage of intervention of masking.

This method has no role when the acute exaggeration will occur; that point should be clarified to the parents.

This method has been named - On Demand Intranasal Steroid Therapy (ODIST). [The patients/ parents are advised to use the intranasal steroid one phial. It takes almost one two months to control the allergic process.

Then keeping another phial on hand; this one is to be used whenever the par e $\mathrm{n} \mathrm{t} \mathrm{s}$ will feel that their baby might have the attack of wheeze. This should be used prior to that, for 5 to 7 days. The parents might use it to their kids, for example, after exposure to hot/cold, change of weather, seasonal changes, and outburst of an epidemic of respiratory disease within community/family].

The drug is used is intranasal fluticasone $0.05 \% \mathrm{w} / \mathrm{v}$ (Flixonase: Gsk..... Nesaflo: Sun... Flomist: Cipla)./mometasone; [MOMEFLOLUPIN].

Though different intranasal steroid have been use d, mostly
Mometasone was preferred. Because Mometasone is safer and can be used in lower age group [6]. Direction: to use it 1 drop in each nostril $\mathrm{OD} / \mathrm{BD}$. The drug may trickle down from the nose; therefore, they were advised to hold the head keeping face upwards for few seconds. The nozzle might be blocked with dried drugs, \& if not possible to clear the passage, they were advised to break the seal \& deliver drug with an ordinary dropper directly into the nose.

\section{Statistical analysis}

Target sample is 65 [as total patients 65 over 2 years of age (including both sexes)]

Type of Study - Active Control Non- Randomised

Type of Trial - Phase - 1

Source - Case Record \& Data

Bank Date of First Enrollment - 06-07-2010.

Estimated Duration of 06-07-2016.

All of them have their Addresses with Me to Correspond and written consent with me.

The result was compared between. Case - [with positive symptoms including all groups with intranasal steroid] \&

. Control - [patients with frequent oral medicine s \& with positive symptoms \& lab investigation some of them was with frequent hospitalization or nursing home admission]

All cases \& among the control group those were in other medicines are improved as per record book \& investigations.

${ }^{\star}$ Conditional maximum likelihood estimate of Rate Ratio (P) indicates a one- tail P - value for Protective or negative association; otherwise one- tailed exact $\mathrm{P}$ - values are for a positive 
Table 6:

Table 6:
\begin{tabular}{|l|r|r|r|}
\hline & $\begin{array}{l}\text { Group A Case With } \\
\text { Intranasal Steroid }\end{array}$ & $\begin{array}{l}\text { Group B Control } \\
\text { Without Intranasal } \\
\text { Steroid }\end{array}$ & Total \\
\hline $\begin{array}{l}\text { WALRI/ASTHMA } \\
\text { Without oral medicine, } \\
\text { inhalers }\end{array}$ & 40 & 10 & 50 \\
\hline $\begin{array}{l}\text { WALRI/ASTHMA } \\
\text { Without oral medicine, } \\
\text { inhalers }\end{array}$ & 10 & 5 & 15 \\
\hline & 50 & 15 & 65 \\
\hline
\end{tabular}

Table 7:

\begin{tabular}{|c|c|c|c|}
\hline & $\begin{array}{c}\text { Group A Case With } \\
\text { intranasal steroid }\end{array}$ & $\begin{array}{c}\text { Group B Control } \\
\text { without intranasal } \\
\text { steroid }\end{array}$ & Total \\
\hline $\begin{array}{c}\text { WALRI/ASTHMA Without } \\
\text { oral medicine, inhalers }\end{array}$ & 40 & 10 & 50 \\
\hline $\begin{array}{c}\text { WALRI/ASTHMA Without } \\
\text { oral medicine, inhalers }\end{array}$ & 10 & 5 & 15 \\
\hline & 50 & 15 & 65 \\
\hline
\end{tabular}

association.

Martin, D; Austin, H (1991) An efficient program for computing conditional maximum likelihood estimates and exact confidence limits for a common odds ratio. Epidemiology 2: 359-362.

Martin, DO; Austin, H (1996) Exact estimates for a rate ratio. Epidemiology 7: 29-33.

Byar $=$ Byar Method; Taylor $=$ Taylor series; PEPI $=$ as described in Abramson and Gahlinger, PEPI software 95\% confidence limits testing exclusion of 0 or 1 , as indicated $\mathrm{P}$ - values $<0.05$ and confidence limits excluding null values $(0,1$, or $[\mathrm{n}])$ are highlighted. Look First items: Editor's choice of items to examine first.

Result s from Open Epi, Version 2, open source calculator Person Time 2

http://www.openepi.com/OE2.3/PersonTime2/PersonTime2. htm

Source file last modified on 09/21/2010 07:40:21

\section{Result}

Total 50 patients were given Intranasal corticosteroid. Out of which 40 patients are on only intranasal corticosteroid \& 10 were with inhaled steroid also.

All of them then advised to follow On Demand Intranasal Steroid Therapy (ODIST). They all are under observation for last eight years, among 40 patients with only INCS, 30 patients are now living a steroid free life intermittently 1.026-0.02275, [DF $=1, \mathrm{CI}=$ with occasional exaggeration that needs, rescuer, inhaler therapy. 10 have now remission of WALRI. Rest 10 patients who were also with inhaled steroid, they are also using this ICS as 'Preventer' rarely.

$$
\mathrm{RR}=1.2, \mathrm{OR}=2 . \mathrm{P}=4.203 \text { at } 95 \%] .
$$

From the statistical analysis \& record - book it is clear that the trial has a positive significance as all 'cases' are on ODIST \& they all are living better than the period of starting INCS in terms of their morbidity, cost \& convenience.
2. Repeated Pefr $+/$ - Spirometry was improved.

3. IgE Levels decreased.

4. Parents Opinions are Positive.

Non e of them has growth retardation. Rather patients having inhaler therapy for more than 2 years with growth retardation showed also in bony age $\mathrm{x}$-ray are now doing well with ODIST.

None have been reported /found any features of HPA- AXIS suppression, any muco - cutaneous symptoms.

Two adults also tried with this therapy, which is giving very good result.

Analysis was made regarding the annual expenditure in this therapy [ON DEMAND INTRANASAL CORTICOSTEROID THERAPY]. And this was correlated with the expenses of preventers with ICS. And the first is much lower.

\section{Discussion}

Usual dosage s for long - term - control medications [9]. From National Asthma Education and Prevention Program (NAEPP) Expert Panel Repor t. Guidelines for the Diagnosis and Management of Asthma-Update on Selected Topics. Washington, DC, NIH, 2002. (NIH publication no: 02-5075).

ODIST \& WALRI: The author with this intranasal steroid in WALRI made a non randomized active cont rolled trial phase- 1 study among the patients over two years of age. And the observation is that intranasal steroid is also an alternative to inhaler steroid as a preventive measure $\&$ this is low cost, easy to deliver. I have started a method to use this intranasal steroids intermittently; calling.

Table 8: z-Score and exact measures of association.

\begin{tabular}{|c|c|c|c|}
\hline Test & Value & p-value(1-tail) & p-value(2-tail) \\
\hline z-score & 2 & 0.02275 & 0.0455 \\
\hline Fisher exact & & 0.02844 & 0.0568 \\
\hline Mid-P exact & & 0.02057 & 0.04115 \\
\hline
\end{tabular}

\section{Table 9:}

\begin{tabular}{|c|c|c|c|}
\hline \multicolumn{2}{|c|}{ Point Estimates } & \multicolumn{2}{c|}{ Confidence Limits } \\
\hline Type & Value & Lower, Upper & Type \\
\hline CMLE Rate Ratio* & 2 & $1.026,4.203^{*}$ & $\begin{array}{c}\text { Mid-P } \\
\text { Exact }\end{array}$ \\
\hline Rate in the exposed & & $0.9829,4.485^{1}$ & $\begin{array}{c}\text { Fisher } \\
\text { Exact }\end{array}$ \\
\hline Rate in the unexposed & 4 & $2.857,5.447$ & Taylor \\
\hline Over all Rate & 2 & $0.955,3.678$ & Taylor \\
\hline Rate Ratio & 3.333 & $2.474,4.395$ & Taylor \\
\hline Rate Difference & 2 & $1,3.999^{1}$ & Byar \\
\hline $\begin{array}{c}\text { Attributable Fractions: Etiologic or } \\
\text { Preventive Etiologic fraction in }\end{array}$ & $40 \%$ & $\begin{array}{c}0.01578 \% \\
66.66 \%{ }^{\circ}\end{array}$ & PEPI \\
\hline $\begin{array}{c}\text { pop.(EFp) Etiologic fraction in exposed } \\
\text { (EFe) }\end{array}$ & $50 \%$ & $\begin{array}{c}0.02366 \%, \\
74.99 \%{ }^{\circ}\end{array}$ & PEPI \\
\hline
\end{tabular}




\section{On demand intranasal steroid therapy}

(ODIST) is a method in this topic used here and is making possible a steroid free life \& ultimately complete/ temporary remission of the symptoms.

An association between allergic rhinitis \& WALRI is well known and intranasal steroid is given for allergic rhinitis (PAR, CAR etc.) [10]. However, their usage in asthma till-date there is no much report. Only a few indirect supports are found from internet [11]. If we look at the drugs of asthma, then two groups will be there. Rescuer / reliever \& preventer b2 agonists, like salbutamol, salmetorol, etc are required to give relief the acute situation; but as a Preventer one can try with intranasal steroid; specially, in intermittat, mild/moderate persistent cases. Intranasal steroid causes no growth retardation, no suppression of HPA axis [12-15].

Odist: A newly coined term stands for on demand intranasal steroid therapy; has made possible a note worthy change in life style of patient as prior administration of short course intranasal steroid therapy could make the patient wheezy bronchitis free life; moreover, it curtails the cost burden of long- term inhale $r$

steroid therapy [16]. Intranasal Corticosteroid: Affects on Rhinitis Comorbidities "It's well accepted that intranasal steroids are the most effective treatment for the symptoms of allergic rhinitis including typical sneezing, itching, rhino rhea and conge s $t$ ion," said Dr. Storms (J Allergy Clin Immunol. 000; 105:489- 494).

The effect of intranasal corticosteoids on treating rhinitis in patient $s$ with asthma has also been studied. Watson and colleague $s$ performed an 8-week, randomized, double- blind, crossover study in 21 patient $\mathrm{s}$ who had perenni al allergic rhinitis and asthma treated with intranasal Beclomethasone or placebo (JACI 1993; 91: 97101). They observed that treatment with the nasal Cortico- steroidreduced symptoms scores for both rhinitis and asthma, although only the rhinitis scores were significantly different. In another study, children with asthma and rhinitis $(\mathrm{n}=26)$ were treated with intranasal Budesonide and it significantly reduced cough and asthma severity (Ann Rev Respir Dis 1984; 130:1014- 1018) [17]. Adams and colleague s examined the effects of intranasal steroid therapy on asthma- related emerge ncy room visits and found that it reduced the number of visits (JACI 2002;109:636-642).

the current consensus of opinion from long- term studies is that intranasal steroids, if used as prescribed, do not have a detrimental effect on growth in children. The data for this are rather scant. There are studies on Mometasonenasal spray and Beclomethasone nasal spray. These studies were performed over 1 year and showed that there was a tendenc $y$ for the Beclome $t$ hason e- treated children to have a slight reduction in growth; whereas the Mometason e- treated children did not have a growth reduction. However, there have not been other studies to confirm the result s of this study, and we cannot make any statement $s$ about the other intranasal steroids. The consensus is that nasal steroids should be used when the patient 's allergies are severe enough to warrant their usage, and they should be used as long as necessary; with this in mind, they are thought to be safe. ' [Will I am W Storms, MD Dire c t o r, The William Storms Allergy Clinic, Colorado Springs, Colorado; Clinical Professor, University of Colorado Health Sciences Center, Denver, Colorado From Medscape
Allergy \& Immunology Effect of Intranasal Corticosteroids on Growth Posted: 04/05/2006 ] Intranasal corticosteroids for asthma control in people with coexisting asthma and rhinitis 'It has been suggested for nearly twenty years that nasal spray s containing corticosterids might improve asthma outcomes in people suffering from both asthma and rhinitis. Intranasal corticosteroids had few side effects in people with mild asthma, but the improvements in symptoms scores and lung function could have arisen by chance. Intranasal corticosteroids may be a promising alternative treatment for patients with rhinitis and mild asthma. More research is needed before considering changing the current practice of prescribing corticosteroids delivered by oral inhalers for asthma, and by nasal sprays for rhinitis'. [This is a Cochrane review abstract and plain language summary, prepared and maintained by The Cochrane Collaboration, currently published in The Cochrane Database of Systematic Reviews 2011 Issue 8, Copyright ( 2011 The Cochrane Collaboration. Published by John Wiley and Sons, Ltd.

The full text of the review is available in The Cochrane Library (ISSN 1464- 780X). Co-Morbid Conditions. Gastroesophageal Reflux (GER) common in asthmatics, with a reported incidence of up to $64 \%$ with GER- related asthma symptoms. If significant GER is noted, reflux precautions should be instituted (no food $2 \mathrm{hr}$ before bedtime, head of the bed elevated 6 in, avoid caffeinated foods and beverages) and medications such as proton pump inhibitor s (omeprazole, lansoprazole) or $\mathrm{H} 2$-receptor antagonists (famotidine, ranitidine) administered for 8 to $12 \mathrm{wk}$ [6]. Rhinitis usually co-morbid with asthma, detected in $\approx 90 \%$ of asthmatic children. Rhinitis can be seasonal and/or perennial, with allergic and non- allergic components. Rhinitis complicates and worsens asthma via numerous

direct and indirect mechanisms. Nasal breathing may reduce exercise- induced bronco- spasm and lower airways dysfunction by humidifying and warming inspired air, and filtering out allergens and irritant $\mathrm{s}$ that can trigger asthma. Optimal rhinitis management in children is similar to asthma management in regards to the importance of interventions to reduce nasal inflammation [7].

According to NAEPP: Higher - level controller therapy: to establish prompt control, with "step down" therapy once good asthma control is achieved [8].

Initially, airflow limitation and the pathology of asthma may limit the delivery and efficacy of Inhaled Cortico-Steroid [ICS].

ICS requires weeks to months of daily administration for optimal efficacy to occur.

Combination pharmacotherapy can provide relatively immediate improvement.

Asthma therapy can be stepped down after good asthma control has been achieved and ICS has had time to achieve optimal efficacy, by determining the least number or dose of daily cont roller medications that can maintain good cont rol, thereby reducing the potential for medication adverse effects.

The NAEPP recommends: Decreasing ICS dose by about $25 \%$ every 2 to $3 \mathrm{mo}$, as long as good asthma control is maintained [8].

Other options: Reducing the frequency of cont roller therapy 
(bidtoqd), discontinuing combination therapy while continuing ICS, or reducing the dose of ICS while maintaining combination therapy [1].

\section{Conclusion}

Intranasal steroid is a safe alternative to inhaler s. It is cost effective also. Easy delivery is also a cause of parents acceptance. Lesser side effects is another favorable point. ON DEMAND, INTRANASAL STEROID THERAPY (ODIST) could also be called RODIST/ ODISTR to keep the doctors name along with has made possible to lead an intermittent steroid free life.

If this system is widely acceptable, there will be great impact on economy of developing country. As WALRI \& asthma are the upcoming burden to the country \& intranasal steroid is cheaper \& this method is making possible to use steroid intermittently.

\section{References}

1. Andrew $H$, Ronina AL, Joseph DC, Donald YM. Leung editors. Childhood asthma (Chapter 143). Kligman Stanton, St Geme, Schor Behrman Pediatrics : Textbook of Nelson, $18^{\text {th }}$ edition.

2. Andrew N, Booth T (1991) The Social Impact of Asthma: Family Practice fampra oxford journals. org. J Fam Pract 8: 37-41.

3. The University of Chicago Medical Center. Comer Children's Hospital at the University of Chicago/ 5721 S. Maryland Avenue/ Chicago, IL 60637.

4. (2011) WHO :ASTHMA: Fact sheet $\mathrm{N}^{\circ} 30$.

5. (2007) NHLBI Guidelines for the diagnosis and treatment of asthma expert panel report 3.
6. NAEPP guideline (National Asthma Education and Prevent ion Programme: Washington DC NIH pub no: 02-5075.

7. 20762 Mometasone Clinical_PREA Pediatric Review www.fda.gov/ downloads/Drugs/.../UCM215 65 9.pdf (mometasonefuroate) Nasal Spray is approved for the treatment of nasal symptoms of allergic rhinitis

8. Immunol J (2002) Allergy Clin Intranasal steroids in asthma management. 2002;109:636-42

9. Durham SR (2002) One airway: the link between allergic rhinitis and asthma Advenc Stud Med 2: 861-866.

10. (2011) Study of Asthma and Nasal Steroids (STAN) This study is currently recruiting par ticipants. Verified on June 2011 by American Lung Association Asthma Clinical Research Centers.

11. Steroid Sparing Effect of Nasal Corticosteroid In Asthma And Rhinitis. This study has been completed. First Received on May 14, 2009. Sponsor \& Information provided by: University of Dundee: ClinicalTrials. gov Identifier: NCT00903227.

12. Taramarcaz P, Gibson PG (2003) Intranasal corticosteroids for asthma cont rol in people with coexisting asthma and rhinitis. Cochrane Database Syst Rev 4: CD003570.

13. (2011) Asthma/Bronchialasthma; Exercise-induced asthma last reviewed.

14. (2014) Exercise-induced asthma.

15. Bahadori K, Doyle-Waters MM, Marra C, Lynd L, Alasaly K, et al. (2009) Economic burden of asthma: a systematic review. BMC Pulm Med 9 : 24.

16. (2012) Johns hopkins health alert: "asthma and gastroesophageal reflux disease (gerd) -- what' s the connect ion?" american academy of allergy, asthma \& immunology: "asthma and gerd", "gast roesophageal reflux disease (GERD)".

17. Bousque $t \mathrm{~J}$, Van Cauwenberge $\mathrm{P}$, Bachert $\mathrm{C}$, et al: requirements for medications commonly used in the treatment of allergic rhinitis. European Academy of Allergy and Clinical Immunology (EAACI). Allergic Rhinitis and its Impact on Asthma (ARIA). Allergy 2003; 58: 192-197. 